\title{
$\beta$-Glucan Increases IFN- $\gamma$ and IL-12 Production of Peripheral Blood Mononuclear Cells with/without Induction of Mycobacterium tuberculosis Wild-type/Mutant DNA
}

\author{
Meira Erawati*, Nyoman Suci Widyastiti, Tri Indah Winarni, Edi Dharmana \\ Faculty of Medicine, Universitas Diponegoro, Jl. Prof. Soedarto, S.H, Tembalang, Semarang, Indonesia \\ *Corresponding author. E-mail: mei_ra07@fk.undip.ac.id
}

Received date: Dec 19, 2018; Revised date: May 2, 2019; Accepted date: May 7, 2019

\section{Abstract}

B

ACKGROUND: In tuberculosis infections, the immune system is weakened and cannot produce enough cytokines to against the infection.

$\beta$-glucan is a potent immunomodulator that induces cytokine production in various bacterial infections. This study aimed to determine the effects of $\beta$-glucan on the production of interferon (IFN)- $\gamma$ and interleukin (IL)-12 in peripheral blood mononuclear cells (PBMCs) induced by Mycobacterium tuberculosis DNA.

METHODS: PBMCs were isolated from 11 healthy subjects. PBMCs were treated with/without $5 \mu \mathrm{g} / \mathrm{mL}$ $\beta$-glucan and $M$. tuberculosis rpoB wild-type or mutant DNA. The production of IFN- $\gamma$ and IL-12 in the supernatant was performed with enzyme-linked immune-sorbent assay (ELISA).

\section{Introduction}

Invasion of Mycobacterium tuberculosis induces immune cells to produce various cytokines. The main cytokines produced are interferon (IFN)- $\gamma$ and interleukin (IL)12. IFN- $\gamma$ is the main activator of macrophages to inhibit the growth of $M$. tuberculosis. IFN- $\gamma$ also plays a role in the process of apoptosis and necrosis of M. tuberculosisinfected macrophages.(1) IFN- $\gamma$ was found at higher levels in tuberculosis (TB) patients compared to non-sufferers.(2) The differences in IFN- $\gamma$ levels from TB patients and healthy people can be used to determine the clinical diagnosis of
RESULTS: $\beta$-glucan increased significantly $(p<0.05)$ IFN- $\gamma$ of $M$. tuberculosis mutant DNA-induced PBMCs, M. tuberculosis wild-type DNA-induced PBMCs, and non-induced PBMCs. $\beta$-glucan also increased significantly $(p<0.05)$ IL-12 of M. tuberculosis mutant DNA-induced PBMCs, M. tuberculosis wild-type DNA-induced PBMCs, and non-induced PBMCs. There were not any significant difference between male and female groups for IL-12 and IFN- $\gamma$ in all treatment groups ( $p>0.05$, ANOVA test).

CONCLUSION: This in vitro study indicates that $\beta$-glucan increases the performance of PBMCs to produce IFN- $\gamma$ and IL-12, with/without induction of M. tuberculosis wild-type/ mutant DNA.

KEYWORDS: $\beta$-glucan, IFN- $\gamma$, IL-12, M. tuberculosis, rров

Indones Biomed J. 2019; 11(2): 200-4 extrapulmonary TB infection in Indonesia.(3) TB infection induces macrophages to produce IL-12. Expression of IL12 during the course of the infection process regulates the natural immune response and separates the type of adaptive immune response. In addition, IL-12 induces IFN- $\gamma$ production.(4)

In pathogenic M. tuberculosis infection, immune cells produce high amount of IFN- $\gamma$ and IL-12. However, insufficient amounts due to immune cells weakening, could be happened in children.(5) To increase the production of cytokines, immune cells need to get external immunomodulators. $\beta$-glucan, a potent immunomodulator, can affect both innate and adaptive immune systems through 
various mechanisms. Dectin-1 is a type II transmembrane protein receptor that can bind with $\beta$-glucan, which later initiate and regulate the natural immune response $(6,7)$, to eliminate bacterial infections and other pathogens.

The use of bacteria DNA as peripheral blood mononuclear cells (PBMCs) inducer was based on the potential of $\mathrm{CpG}$ oligodeoxynucleotide motifs in the evidenced DNA of the bacteria to induce the production of various cytokines and nitric oxide (NO) in immune cells, in which some are indicators of inflammation. $(8,9)$ Based on previous research, the wild-type strain of $M$. tuberculosis found in Indonesia was Beijing strain H37Rv, whereas the most mutation of bacterial resistance to rifampicin first-line anti-TB drug was the mutation of the rpoB gene.(10) Treatment of these bacteria is still being developed to date, especially when the bacteria show resistance to anti-TB drugs. Therefore, current research was conducted to investigate the potential of $\beta$-glucan as an immunomodulator in both types of TB infections caused by M. tuberculosis wild-type and mutants based on IFN- $\gamma$ and IL-12 production.

\section{Methods}

\section{Study Subject}

The study subjects were 5 men and 6 women, who signed the informed consent. They were selected and recruited based on the inclusion and exclusion criteria. The inclusion criteria were healthy and aged 18-25 years. Meanwhile, the exclusion criteria were suffering from acute or chronic diseases, having positive test results for HIV, hepatitis B and/or hepatitis $\mathrm{C}$, consuming immunosuppressant and/or immunomodulator, and undergoing surgery within 6 months prior to the study. This research protocol was approved by the Health Research Ethics Committee of the Faculty of Medicine Universitas Diponegoro and Dr Kariadi Hospital Semarang (469/EC/FK-RSDK/VII/2017).

\section{M. tuberculosis DNA Isolation, PCR and Sequence}

DNA isolation was carried out using DNeasy Blood and Tissue kits (Catalog \#69504, Qiagen, Hilden, Germany). Briefly, M. tuberculosis H37Rv was lysed using proteinase $\mathrm{K}$. Then the lysate was loaded onto the DNeasy Mini spin column and centrifuged. DNA was selectively bound to the DNeasy membrane. Remaining contaminants and enzyme inhibitors were washed twice and DNA was then eluted in buffer. The $411 \mathrm{bp}$ of rpoB fragment was produced using PCR with the forward primer
5'-TACGGTCGGCGAGCTGATCC-3' and reverse primer 5'-TACGGCGTTAGCTCGATG-3' for 35 cycles. The products were electrophorized on $1.5 \%$ agarose gel, stained with ethidium bromide, and confirmed by visualizing with ultraviolet. PCR products were then sequenced using automated DNA sequencer (Applied Biosystems, Foster City, CA, USA), analyzed using Basic Local Alignment Search Tool (BLAST) of the National Center for Biotechnology Information (NCBI), and compared to the reference genome of wild-type M. tuberculosis H37Rv.

\section{PBMCs Isolation and Induction}

Peripheral blood in the volume of $5 \mathrm{~mL}$ was collected from each subject. Then the blood was poured on Ficoll density gradient and centrifuged. The PBMCs were carried out and washed twice with PBS, then added with complete RPMI media. PBMCs in number of $5 \times 10^{5}$ were cultured in 24-well plates with complete RPMI media, then treated with/without $5 \mu \mathrm{g} / \mathrm{mL} \beta$-glucan (Merck KGaA, Darmstadt, Germany) and $10 \mu \mathrm{g} / \mathrm{mL}$ M. tuberculosis wild-type or mutant DNA. PBMCs were incubated in a humidified incubator of $5 \% \mathrm{CO}_{2}$ at $37^{\circ} \mathrm{C}$ for 6 days. The supernatant was harvested as test sample and analyzed for IFN- $\gamma$ and IL-12 production with enzyme-linked immunesorbent assay (ELISA).

\section{ELISA}

IFN- $\gamma$ and IL-12 measurement was done in duplo using the Human IFN- $\gamma$ ELISA kit (Fine Test, Hubei, China) and the Human IL-12 ELISA kit (Fine Test). Both kits had similar principle and the test was performed according to the instruction manual. Anti-IFN- $\gamma$ or Anti-IL-12 antibody was pre-coated onto 96-well plates. Standards, test samples and biotin conjugated anti-IFN- $\gamma$ or Anti-IL-12 antibody were added to the wells subsequently, and washed. Horseradish peroxidase (HRP)-Streptavidin was added and unbound conjugates were washed. The 3,3',5,5'-tetramethylbenzidine (TMB) substrates were used to visualize. A blue color product changed into yellow after adding acidic stop solution. Optical density absorbance was read at $450 \mathrm{~nm}$ in a microplate reader, then the concentration of IFN- $\gamma$ or IL12 was calculated.

\section{Statistical Analysis}

Statistical analysis was performed using SPSS Statistics version 20 (IBM Corp, Armonk, NY, USA). Mann-Whitney $\mathrm{U}$ test was carried out for all paired comparisons between $\beta$-glucan and non $\beta$-glucan-treated PBMCs, to compare the mean differences of IFN- $\gamma$ and IL-12 levels with a 
confidence level of $95 \%$ and $p<0.05$. Analysis of IFN $\gamma$ and IL-12 levels differences between male and female was conducted by analysis of variance (ANOVA) test.

\section{Results}

\section{PCR Product and DNA Sequence}

Size of M. tuberculosis rpoB PCR products were confirmed as 411 bp (Figure 1). DNA sequence results showed a variation of the rpoB at codon 351, initially TCG changed to TTG. Meanwhile Figure 2 showed variation of the M. tuberculosis rpoB base at codon 513 .

\section{IL-12 and IFN- $\gamma$}

In current result, higher IL-12 and IFN- $\gamma$ productions of PBMCs from male group than the productions of PBMCs from female group, were obtained (Figure 3A). The highest IL-12 level $(195.35 \mathrm{pg} / \mathrm{mL})$ was produced by $M$. tuberculosis wild-type DNA and $\beta$-glucan-treated PBMCs from female group. Meanwhile, the lowest IL-12 level (54.62 $\mathrm{pg} / \mathrm{mL}$ ) was produced by M. tuberculosis wild-type DNA-induced PBMCs from female group. The highest IFN- $\gamma$ level $(72.38 \mathrm{pg} / \mathrm{mL})$ was produced by $M$. tuberculosis mutant DNA and $\beta$-glucan-treated PBMCs from female group. Meanwhile, the lowest IFN- $\gamma$ level $(32.5 \mathrm{pg} / \mathrm{mL})$ was produced by non-induced PBMCs from female group. However, there were not any significant difference between male and female groups for IL-12 and IFN- $\gamma$ in all treatment groups ( $p>0.05$, ANOVA test).

$\beta$-glucan increased significantly $(p<0.05) \quad$ IFN $-\gamma$ of $M$. tuberculosis mutant DNA-induced PBMCs, M. tuberculosis wild-type DNA-induced PBMCs, and non-induced PBMCs (Table 1). $\beta$-glucan also increased

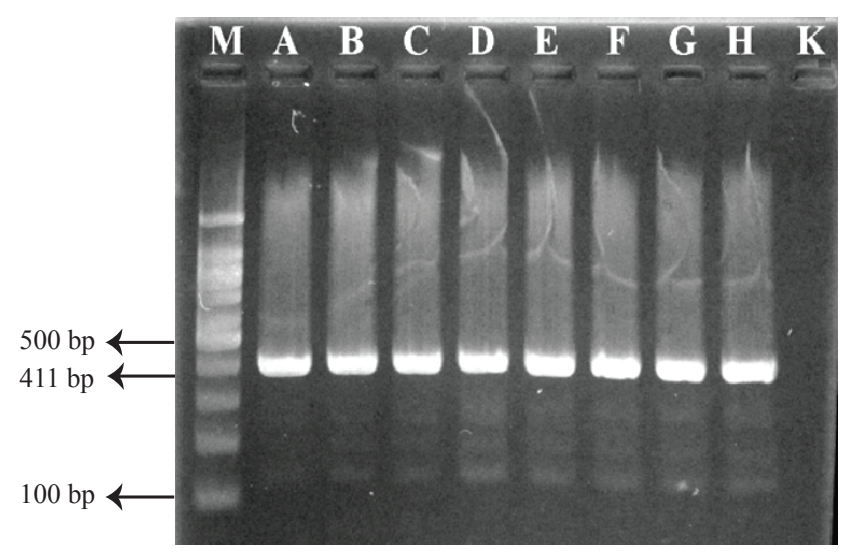

Figure 1. The PCR products of M. tuberculosis rpoB. M: size marker; A-H: PCR products of M. tuberculosis; K: control.

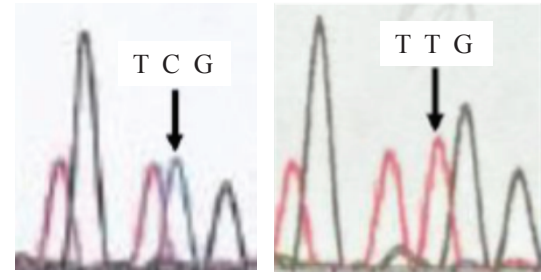

Figure 2. Variation of the M. $t$ uberculosis $r p o B$ base at codon 513.

significantly $(p<0.05)$ IL-12 of $M$. tuberculosis mutant DNA-induced PBMCs, M. tuberculosis wild-type DNAinduced PBMCs, and non-induced PBMCs.

\section{Discussion}

IFN- $\gamma$ and IL-12 are the main cytokines produced by T-lymphocytes and macrophages during TB infection, which function as one form of body defense to eliminate infection.(11) To counter TB infection, IFN- $\gamma$ and IL-12 must be produced in sufficient quantities. Current results showed that PBMCs treated with $\beta$-glucan produced significantly higher IFN- $\gamma$ than PBMCs untreated with $\beta$-glucan. These results were in line with previous study that described orally-administered $\beta$-glucan enhanced IFN- $\gamma$ production in BALB/c mice.(12) Increasing IFN- $\gamma$ production modulated by $\beta$-glucan is not only observed in PBMCs, but also in serum.(11) In addition, oral mushroom $\beta$-glucan treatment significantly increased IFN- $\gamma$ and IL-12 mRNA expression.(13)

Besides IFN- $\gamma$ production, current results also showed that PBMCs treated with $\beta$-glucan produced higher IL-12 than PBMCs untreated with $\beta$-glucan. In previous study, $\beta$-glucan administration primed spleen cells for a higher production of IL-12.(14) In contrast, neutralization of IL12 activity by anti-IL-12 decreased IFN- $\gamma$ synthesis. These data suggest that $\beta$-glucan may support anti-tumour and anti-infective immune responses by increasing IL-12induced IFN- $\gamma$ production by $\mathrm{T}$ cells.(4). $\beta$-glucan from Saccharomyces cerevisiae is one of the polysaccharides that has been proven to increase the production of IFN- $\gamma$ and IL-12 in vitro.(11) In previous study, orally administered $\beta$-glucan reduced the progression of decreased white blood cell (WBC) count and increased the production of IL-4 and IL-12 in breast cancer patients when compared with the placebo control group.(15)

$\beta$-glucans inhibit growth of $M$. tuberculosis in host cells in vitro, probably due to cellular induction and/or competitive inhibition of uptake of bacteria via complement 
A

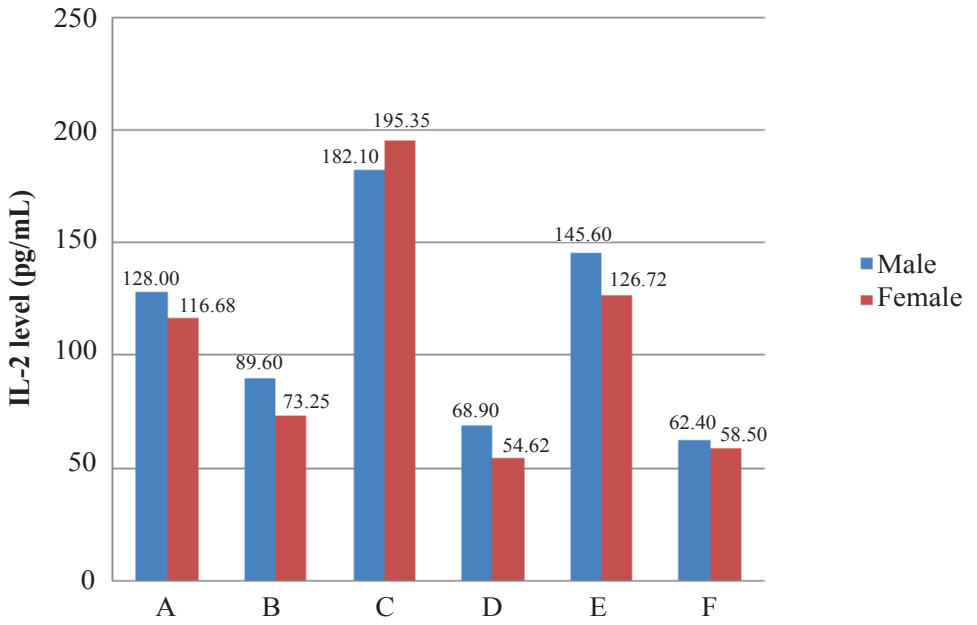

B

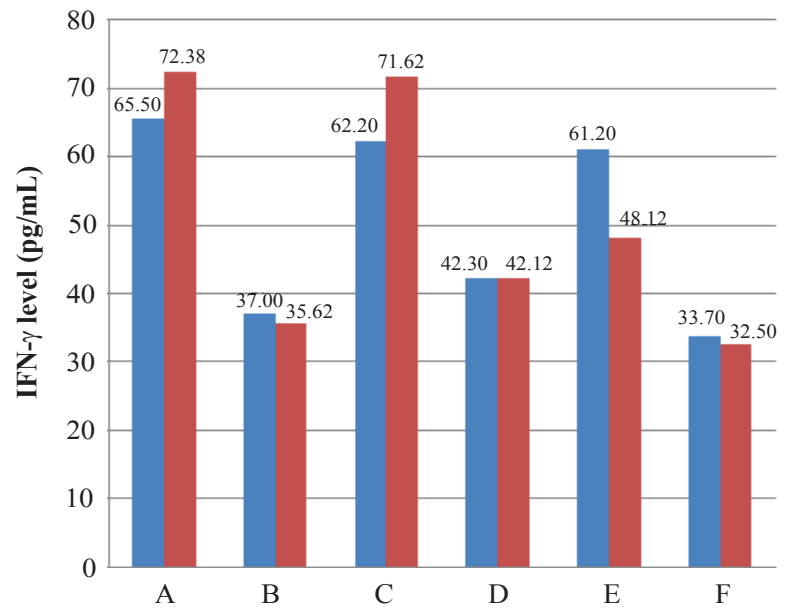

- Male

- Female
Figure 3. IL-12 and IFN- $\gamma$ production of PBMCs from male and female groups. A: PBMCs were treated with $M$. tuberculosis mutant DNA and $\beta$-glucan; B: M. tuberculosis mutant DNA merely; C: $M$. tuberculosis wildtype DNA and $\beta$-glucan; D: M. tuberculosis wild-type DNA merely; E: $\beta$-glucan merely; F: PBMCs were not induced. receptor (CR)3 (cluster of differentiation (CD)11b/18) (16), where the study showed that $\beta$-glucan has the potential to treat TB infections. There was a dose-dependent effect of $\beta$-glucan injected before Bacillus Calmette-Guérin (BCG) challenge on the number of BCG bacilli found in spleen and liver homogenates. In addition, antibody cross-

Table 1. Differences of IL-12 and IFN $\gamma$ - levels based on $\beta$-glucan treatment status.

\begin{tabular}{|c|c|c|c|c|c|}
\hline \multirow[b]{2}{*}{ Type of Induction } & \multirow{2}{*}{$\begin{array}{c}\beta \text {-Glucan } \\
\text { Treatment }\end{array}$} & \multicolumn{2}{|c|}{ IFN- $\gamma$} & \multicolumn{2}{|c|}{ IL-12 } \\
\hline & & $\begin{array}{c}\text { MeantSD } \\
(\mathbf{p g} / \mathrm{mL})\end{array}$ & $p$-value & $\begin{array}{c}\text { MeantSD } \\
(\mathrm{pg} / \mathrm{mL})\end{array}$ & $p$-value \\
\hline \multirow{2}{*}{$\begin{array}{l}\text { M. tuberculosis mutant } \\
\text { DNA-induced PBMCs }\end{array}$} & With $\beta$-glucan & $68.6 \pm 17.90$ & 0.000 & $122.9 \pm 11.16$ & 0.001 \\
\hline & Without $\beta$-glucan & $36.4 \pm 4.87$ & & $82.3 \pm 26.23$ & \\
\hline \multirow{2}{*}{$\begin{array}{l}\text { M. tuberculosis wild-type } \\
\text { DNA-induced PBMCs }\end{array}$} & With $\beta$-glucan & $66.4 \pm 10.50$ & 0.000 & $188.0 \pm 26.36$ & 0.000 \\
\hline & Without $\beta$-glucan & $42.2 \pm 4.06$ & & $62.6 \pm 13.69$ & \\
\hline \multirow{2}{*}{$\begin{array}{l}\text { Non-induced PBMCs } \\
\text { (control) }\end{array}$} & With $\beta$-glucan & $55.4 \pm 10.90$ & 0.001 & $137.2 \pm 24.05$ & 0.000 \\
\hline & Without $\beta$-glucan & $33.2 \pm 5.25$ & & $60.7 \pm 7.32$ & \\
\hline
\end{tabular}

*Tested with Mann-Whitney U Test. 
reactivity was demonstrated between $M$. tuberculosis cell wall and $\beta$-glucan. Previous results suggested that $\beta$-glucan has a protective effect against Mycobacterium bovis, BCG infection in susceptible mice.(17)

Increased production of IFN- $\gamma$ and IL-12 in current study has been observed due to potential of $\beta$-glucan to increase the differentiation of monocyte cells into macrophages (18), with the help of other cytokines during differentiation process through nonapoptotic, and caspase3-dependent mechanisms (19).

\section{Conclusion}

This research indicates that $\beta$-glucan can improve the performance of PBMCs to produce IFN- $\gamma$ and IL-12, with/ without induction of $M$. tuberculosis wild-type/mutant DNA. The results of this study should be followed up by in vivo research.

\section{Acknowledgements}

The authors would like to express acknowledgment to Suprihatin for her technical assistance with laboratory work and all participants. Furthermore, the authors also express gratitude to Ministry of Research, Technology and Higher Education of the Republic of Indonesia for the research funding of this study (No. of the Contract. 275-22/UN7.5.1/ PG/2017).

\section{References}

1. Lee J, Hartman M, Kornfeld H. Macrophage apoptosis in tuberculosis. Yonsei Med J. 2009; 50: 1-11.

2. Sinaga B, Tarigan A. The difference of interferon gamma level in pulmonary tuberculosis patients and healthy control in Medan, Indonesia. Respirology. 2017; 22: 133. doi:10.1111/resp.13207_134.

3. Rumende C, Hadi E, Tanjung G, Saputri I, Sasongko R. The benefit of interferon-gamma release assay for diagnosis of extrapulmonary tuberculosis. Indones J Intern Med. 2018; 50: 138-43.

4. Budak F, Goral G, Oral HB. Saccharomyces cerevisiae beta-glucan induces interferon-gamma production in human T cells via IL-12. Turk J Immunol. 2008; 13: 21-6.
5. Daulay RS, Daulay RM. Interferon-gamma and interleukin-10 profile of children with tuberculosis in North Sumatera, Indonesia. IOP Conf Series: Earth and Environmental Science. 2018; 125: 012147. doi :10.1088/1755-1315/125/1/012147.

6. Brown G, Herre J, Williams D, Willment J, Marshall A, Gordon S. Dectin-1 mediates the biological effects of $\beta$-glucans. J Exp Med. 2003; 197: 1119-24.

7. Herre J, Marshall A, Caron E, Edwards A, Williams D, Schweighoffer $\mathrm{E}$, et al. Dectin-1 uses novel mechanisms for yeast phagocytosis in macrophages. Blood. 2004. 104: 4038-45.

8. Wattrang E, Palmb A, Wagnerc B. Cytokine production and proliferation upon in vitro oligodeoxyribonucleotide stimulation of equine peripheral blood mononuclear cells. Vet Immunol Immunopathol. 2012; 146: 113-24.

9. Tavakoli Z, Ardestani SK, Lashkarbolouki T, Kariminia A, Salehi TZ, Tavassoli N. DNAs from Brucella strains activate efficiently murine immune system with production of cytokines, reactive oxygen and nitrogen species. Iran J Allergy Asthma Immunol. 2009; 8: 127-34.

10. Erawati M, Andriany M, Kusumaningrum NSD. Mutation in the rpoB gene of multidrugs-resistant Mycobacterium tuberculosis isolates from Semarang. Int J Mol Clin Microb. 2017; 7: 818-23.

11. Zhang B, Guo YM, Wang Z. The modulating effect of beta1,3/1,6-glucan supplementation in the diet on performance and immunological responses of broiler chickens. Asian-Australas J Anim Sci. 2008; 21: 237-44.

12. Javmen A, Nemeikaitė-čẻnienė A, Bratchikov $\mathrm{M}$, Grigiškis $\mathrm{S}$, Grigas F, Jonauskienė I, et al. $\beta$-Glucan from Saccharomyces cerevisiae Induces IFN- $\gamma$ Production In Vivo in BALB/c Mice. In vivo. 2015; 29: 359-64.

13. Wang W, Wu Y, Chen S, Liu C, Chen S. Mushroom $\beta$-glucan may immunomodulate the tumor-associated macrophages in the lewis lung carcinoma. Biomed Res Int. 2015; 2015: 604385. doi: $10.1155 / 2015 / 604385$.

14. Pelizon AC, Kaneno R, Soares AMVC, Meira DA, Sartori A. Immunomodulatory activities associated with $\beta$-glucan derived from Saccharomyces cerevisiae. Physiol Res. 2005; 54: 557-64.

15. Lee SB, Kim YH, Hyun MC, Kim YH, Kim HS, Lee YH. T-helper cytokine profiles in patients with kawasaki disease. Korean Circ J. 2015; 45: 516-21.

16. Hetland G, Sandven P. 1,3-glucan reduces growth of Mycobacterium tuberculosis in macrophage cultures. FEMS Immunol Med Microbiol. 2002; 33: 41-5.

17. Saito M, Nagasawa M, Takada H, Hara T, Tsuchiya S, Agematsu $\mathrm{K}$, et al. Defective IL-10 signaling in hyper-IgE syndrome results in impaired generation of tolerogenic dendritic cells and induced regulatory T cells. J Exp Med. 2011; 208: 235-49.

18. Salem SAM, Diab HM, Fathy G, Obia LM, El Sayed SB. Value of interleukins 4,10,12, 18 and interferon gamma in acute versus chronic atopic dermatitis. J Egypt Women Dermatol Soc. 2010; 7: 56-60.

19. Miura M. Apoptotic and nonapoptotic caspase function in animal development. Cold Spring Harb Perspect Biol. 2016; 4: a008664. doi: 10.1101/cshperspect.a008664. 